\title{
Gimballed Limb Observer for Radiance Imaging of the Atmosphere (GLORIA) scientific objectives
}

\author{
M. Riese ${ }^{1}$, H. Oelhaf ${ }^{2}$, P. Preusse ${ }^{1}$, J. Blank ${ }^{1}$, M. Ern ${ }^{1}$, F. Friedl-Vallon ${ }^{2}$, H. Fischer ${ }^{2}$, T. Guggenmoser ${ }^{1}$, M. Höpfner ${ }^{2}$, \\ P. Hoor ${ }^{3}$, M. Kaufmann ${ }^{1}$, J. Orphal ${ }^{2}$, F. Plöger ${ }^{1}$, R. Spang ${ }^{1}$, O. Suminska-Ebersoldt ${ }^{2}$, J. Ungermann ${ }^{1}$, B. Vogel ${ }^{1}$, and \\ W. Woiwode ${ }^{2}$ \\ ${ }^{1}$ Institute of Energy and Climate Research, Stratosphere (IEK-7), Forschungzentrum Jülich, 52425 Jülich, Germany \\ ${ }^{2}$ Institute for Meteorology and Climate Research, Karlsruhe Institute of Technology, Karlsruhe, Germany \\ ${ }^{3}$ Institute for Atmospheric Physics, University Mainz, Mainz, Germany \\ Correspondence to: M. Riese (m.riese@fz-juelich.de)
}

Received: 23 December 2013 - Published in Atmos. Meas. Tech. Discuss.: 14 February 2014

Revised: 12 May 2014 - Accepted: 26 May 2014 - Published: 2 July 2014

\begin{abstract}
The upper troposphere/lower stratosphere (UTLS) represents an important part of the climate system. Even small changes in the composition and dynamic structure of this region have significant radiative effects. Quantifying the underlying physical and chemical processes therefore represents a crucial task. Currently, there is a lack of UTLS observations with sufficient three-dimensional resolution. The Gimballed Limb Observer for Radiance Imaging of the Atmosphere (GLORIA) aircraft instrument addresses this observational lack by providing observations of numerous trace constituents as well as temperature and cloud structures with an unprecedented combination of vertical resolution (up to $300 \mathrm{~m}$ ) and horizontal resolution (about $30 \mathrm{~km} \times 30 \mathrm{~km}$ ). As a result, important scientific questions concerning stratosphere-troposphere exchange, the occurrence of subvisible cirrus clouds in the lowermost stratosphere (LMS), polar chemistry, and gravity wave processes can be addressed, as reviewed in this paper.
\end{abstract}

\section{Introduction}

Changes and variability of upper troposphere/lowere stratosphere (UTLS) composition are major drivers of surface climate change (e.g. Solomon et al., 2007, 2010). Even small changes of greenhouse gases such as water vapour $\left(\mathrm{H}_{2} \mathrm{O}\right)$ and ozone $\left(\mathrm{O}_{3}\right)$, aerosols, and cirrus clouds have significant effects on the atmospheric radiation balance. Improved prediction capabilities of chemistry-climate models (CCM) therefore rely on a realistic representation of UTLS processes affecting UTLS composition.

UTLS composition is governed by the complex interactions of various physical and chemical processes that operate at a wide range of temporal and spatial scales (local to global) as illustrated in Fig. 1. Water vapour and ozone are particularly sensitive to atmospheric transport due to their steep spatial mixing ratio gradients in this region. Small-scale trace gas filaments in the UTLS represent an important example of structures that are not yet adequately characterised. They arise from chaotic advection of tracers, driven by the largescale flow (e.g. Aref, 1984; Pierce and Fairlie, 1993). Dissipation of such trace gas structures results from a scale collapse, which occurs in regions of strong wind shear rates. Riese et al. (2012) showed that even small uncertainties in this dissipation process (mixing strength) have a significant influence on simulated UTLS composition, for example on water vapour and ozone concentrations, and associated radiative effects (see Fig. 2).

Most progress in understanding small-scale processes in the UTLS has been made on the basis of detailed airborne in situ observations. Satellite limb observations, e.g. by the Michelson Interferometer for Passive Atmospheric Sounding (MIPAS) onboard Envisat (Fischer et al., 2008), provided a global view, albeit at limited spatial resolution. Currently, there is a gap of observations concerning small-scale trace gas structures and temperature fluctuations, with a vertical extent of less than $500 \mathrm{~m}$ and a horizontal extent of less than $100 \mathrm{~km}$. The Gimballed Limb Observer for Radiance 


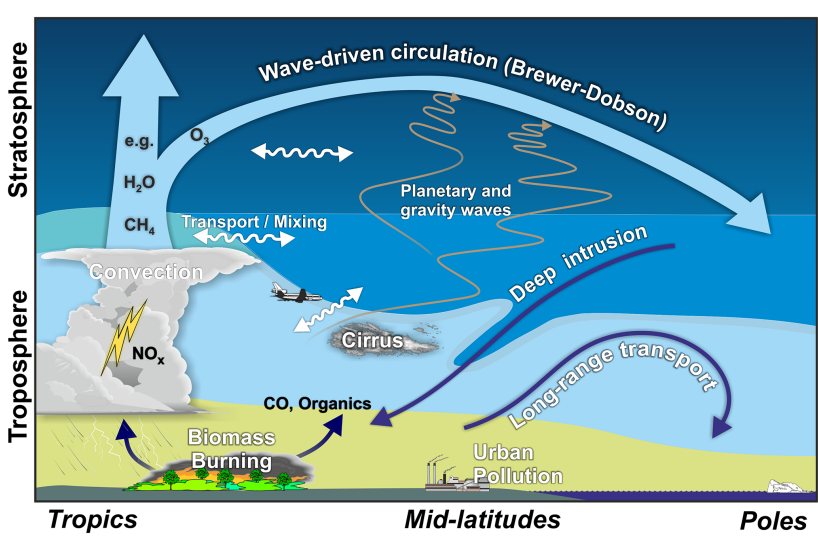

Figure 1. Processes that determine UTLS composition. The middle shaded blue region is the lowermost stratosphere (LMS), where isentropic surfaces cross the tropopause and facilitate quasihorizontal transport (middle white wave-like arrow). More details on transport in the tropopause region are given in Fig. 9.

Imaging of the Atmosphere (GLORIA) is designed to provide information on important atmospheric processes in this observational gap by two- and three-dimensional observations with unprecedented spatial resolution.

Our paper is part of an Atmospheric Measurement Techniques (AMT) special issue, "Atmospheric limb imaging with GLORIA", that describes all technical aspects of the GLORIA aircraft instrument, including the design of the overall system and the individual components (e.g. optics, attitude control, electronics) as well as the data processing from level 0 (raw data) to level 2 (atmospheric temperatures and trace gas mixing ratios). We also describe the scientific applications which have driven the instrument design. Furthermore, the paper shall serve as a link between the technically oriented publications of the special issue and the science questions that will be addressed in the coming years, e.g. in the framework of several aircraft campaigns.

Section 2 starts with a brief review of the history of infrared emission limb sounding, with a special focus on spatial and spectral resolution. To advance UTLS science, the infrared emission limb-imaging technique was originally proposed for satellite-based global observations (Riese et al., 2005; Friedl-Vallon et al., 2006). The GLORIA aircraft instrument represents the first airborne realisation of this technique. To measure three-dimensional temperature and trace gas distributions from a research aircraft, tomographic measurement modes were implemented. The design of the instrument and its measurement modes are briefly described in Sect. 3. We also show first trace gas observations, which were obtained during the first scientific employment in summer/autumn 2012. These observations demonstrate the successful implementation of the new instrument concept. Section 4 gives an overview of the specific themes that can be addressed by GLORIA in upcoming aircraft campaigns. The section complements previous overviews of UTLS science addressable by the limb-imaging technique (e.g. ESA, 2012; Riese et al., 2005) by highlighting those themes, where major contributions can be expected from an aircraft instrument, despite limitations in temporal, geographical, and altitude coverage.

\section{Infrared limb sounding}

Infrared limb emission sounders measure the radiance emitted by the atmosphere along the line of sight (LOS) as illustrated in Fig. 3. The method provides high vertical resolution since the LOS segment of the layer above the tangent point (closest point to the Earth surface) is relatively large compared to other segments and the total density of the atmosphere exponentially decreases with altitude. Global observations of atmospheric infrared limb emissions were therefore made by a number of low-Earth-orbit satellite instruments to measure vertically resolved profiles of temperature, a variety of trace gases, aerosols, and clouds simultaneously, at daytime and night-time (e.g. Drummond et al., 1980; Gille and Russel III, 1984; Roche et al., 1993; Taylor et al., 1993; Bingham et al., 1997; Offermann et al., 1999; Russell et al., 1999; Fischer et al., 2008; Gille et al., 2008). These satellite observations significantly enhanced our understanding of the 3-D chemical structure and large-scale dynamics of the middle atmosphere.

For improved horizontal resolution, the Cryogenic Infrared Spectrometers and Telescopes for the Atmosphere (CRISTA) instrument onboard the Shuttle Palette Satellite (SPAS) employed three telescopes that scanned the Earth horizon in the altitude range from 10 to $100 \mathrm{~km}$ at horizontal angles of $18^{\circ}$ apart. By this approach, the large horizontal measurement gap between subsequent orbits, about $2000 \mathrm{~km}$ at the Equator, could be filled and a horizontal across-track sampling of about $600 \mathrm{~km}$ was achieved. The along-track sampling was 200 to $400 \mathrm{~km}$, depending on the measurement mode. CRISTA was successfully operated during two missions of NASA's Space Shuttle STS66 in November 1994 (Offermann et al., 1999) and STS85 in August 1997 (Grossmann et al., 2002). During its one-week missions, the instrument provided global snap shots of stratospheric and mesospheric temperature and about 10 trace gases (Riese et al., 1997, 1999a) with the best three-dimensional spatial resolution of global trace gas observations achieved to date. Parts of the CRISTA optical system were later re-used on the high-flying Russian research aircraft M55-Geophysica by the CRISTA-New Frontiers (NF) instrument for limb observations in the UTLS with unprecedented vertical resolution and along flight-track sampling (e.g. Kullmann et al., 2004; Ungermann et al., 2012).

To acquire the most complete set of composition data of the stratosphere, pole to pole over almost a full solar cycle, MIPAS on ESA's Envisat was focusing on high spectral 

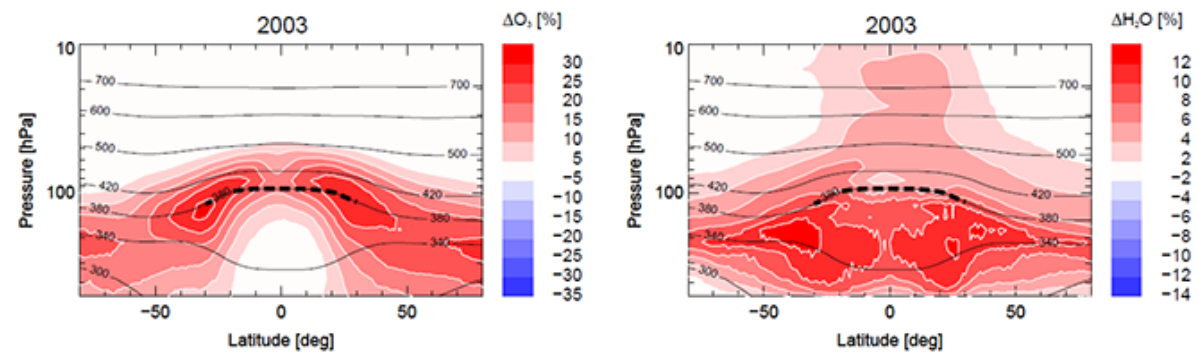

Figure 2. Influence of uncertainties in the atmospheric mixing strength on simulated UTLS ozone (left) and water vapour (right). Shown are percentage differences for zonally averaged values (2003) obtained for two simulations with the Chemical Lagrangian Model of the Stratosphere (CLaMS), spanning the current uncertainty range of atmospheric mixing strength. For details see Riese et al. (2012).

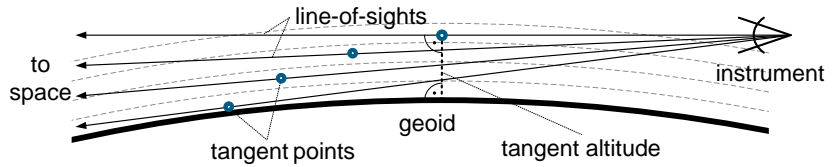

Figure 3. Limb-viewing geometry for a limb sounder. The instrument measures the radiance emitted by the atmosphere along the line of sight (LOS). The LOS altitude that is closest to the Earth surface is the tangent altitude; the corresponding point is the tangent point. The limb-viewing geometry yields relatively good vertical resolution as a result of the spherical geometry and the exponential decrease of atmospheric density with altitude. GLORIA records radiance from all LOS simultaneously.

rather than high spatial resolution. It was operating from 2002 until 2012. By observing the 4 to $15 \mu \mathrm{m}$ range at very high-spectral sampling, up to 40 atmospheric trace gases could be measured in the nominal altitude range from 6 to $68 \mathrm{~km}$ (in some modes extended up to $150 \mathrm{~km}$ ) at 2 to $4 \mathrm{~km}$ vertical spacing and 300 to $500 \mathrm{~km}$ along-track sampling (Fischer et al., 2008). The development of MIPAS onboard Envisat was based on experience with the balloon-borne precursor MIPAS-B (Fischer and Oelhaf, 1996; Friedl-Vallon et al., 2004) and was later complemented by the MIPASSTR instrument onboard M55-Geophysica (e.g. Piesch et al., 1996; Woiwode et al., 2012).

A new scientific focus of infrared limb sounding is the region of the UTLS owing to its immense importance for the climate system. Airborne limb emission sensors such as MIPAS-STR and CRISTA-NF are characterised by adequate spatial sampling in the UTLS in two dimensions (vertical and along the flight track) but no spatial sampling in the viewing direction. Lidar observations typically measure two-dimensional curtains (vertical $\times$ flight direction) of a few atmospheric species such as $\mathrm{H}_{2} \mathrm{O}$ or $\mathrm{O}_{3}$. Many UTLS objectives require, however, precise three-dimensional observations of temperature and multiple trace gases with a vertical resolution better than $1 \mathrm{~km}$ and a horizontal resolution of a few 10s of kilometres (e.g. ESA, 2012). To fulfil this requirement, atmospheric limb imaging was proposed (Riese et al., 2005; Friedl-Vallon et al., 2006), which combines high spatial resolution in three-dimensions with high spectral resolution, i.e. a high number of detectable species.

The infrared limb-imaging technique basically combines two-dimensional detector arrays with Fourier transform spectroscopy for about $10^{3}$ to $10^{4}$ simultaneous limb views in the mid-infrared spectral region. The capabilities of this technique were studied for application on a satellite in the framework of the Earth Explorer (EE-7) program by the European Space Agency (ESA, 2012). It could be shown that global limb imaging would result in a significant reduction of uncertainties in key physical and chemical processes in the atmosphere that are currently limiting the predictive capabilities of Earth system and climate models. The concept will therefore be further studied in the framework of the ESA Earth Explorer programme and for a proposed German limbimaging mission (ATMO-SAT).

\section{Airborne infrared limb imaging with GLORIA}

Previous airborne limb emission sounders such as MIPASSTR and CRISTA-NF onboard the high-flying Russian aircraft M55-Geophysica measure multiple trace gases in the UTLS with high spatial sampling in two dimensions, vertically up to $200 \mathrm{~m}$ and up to $20 \mathrm{~km}$ along the flight track. These instruments were successfully employed during the tropical SCOUT-O3 aircraft campaign in 2005 (e.g. Spang et al., 2008; Hoffmann et al., 2009), in the framework of the tropical TROCCINOX and the ENVISAT validation campaigns (Keim et al., 2008), during AMMA-SCOUT in 2006 (e.g. Weigel et al., 2010, 2012; Ungermann et al., 2013), and during the Arctic RECONCILE aircraft campaign in 2010 (e.g. Woiwode et al., 2012; Kalicinsky et al., 2013; von Hobe et al., 2013).

While CRISTA-NF and MIPAS-STR provide excellent sampling and resolution along the flight track, the resolution perpendicular to the flight track is limited by the relative broad weighting functions (about $200 \mathrm{~km}$ ) of the atmospheric radiative transfer. Also due to the single detector approach some measurement time is used up for scanning over the 
limb, resulting in an irregular sampling of the atmosphere. These limitations can be overcome by using a 2-D detector instead of single detectors, enabling limb-imaging instead of limb scanning (Friedl-Vallon et al., 2014). In addition, this technique offers a way to get better information on the third horizontal dimension (i.e. along the line of sight) by applying tomographic techniques. GLORIA represents the first realisation of the infrared limb-imaging technique. Its first technical deployments took place onboard M55-Geophysica during the ESA Sounder Campaign 2011 (Essence-11) in December 2011 from Kiruna (Sweden). In summer/autumn 2012, GLORIA was deployed on HALO during the Transport and Composition in the UT/LMS (TACTS) and Earth System Model Validation (ESMVal) campaigns. Future aircraft campaigns are discussed in Sect. 4.

\subsection{GLORIA instrument concept and measurement modes}

GLORIA combines a classical Fourier transform spectrometer with a 2-D detector array. The instrument takes limb images of the atmosphere from the flight altitude of HALO or M55-Geophysica down to $4 \mathrm{~km}$, using a vertical sampling step of about $150 \mathrm{~m}$ at $10 \mathrm{~km}$ tangent height. Individual images contain 128 pixels (spectra) in the vertical dimension and 48 pixels in the horizontal dimension. The spectral range of the observations currently extends from about 780 to $1400 \mathrm{~cm}^{-1}$. The list of measurable quantities includes temperature, $\mathrm{H}_{2} \mathrm{O}, \mathrm{HDO}, \mathrm{O}_{3}, \mathrm{CH}_{4}, \mathrm{~N}_{2} \mathrm{O}, \mathrm{CFC}-11$, CFC-12, HCFC-12, $\mathrm{SF}_{6}, \mathrm{HNO}_{3}, \mathrm{~N}_{2} \mathrm{O}_{5}, \mathrm{ClONO}_{2}, \mathrm{HO}_{2} \mathrm{NO}_{2}, \mathrm{PAN}$, $\mathrm{C}_{2} \mathrm{H}_{6}, \mathrm{H}_{2} \mathrm{CO}, \mathrm{NH}_{3}$, and cirrus cloud quantities like effective radii and ice water content (IWC). Details on the instrument design and calibration are given in the accompanying publications of Friedl-Vallon et al. (2014) and Kleinert et al. (2014).

GLORIA is operated in a high-spectral, medium-spatial sampling ("chemistry") mode and a medium-spectral, highspatial sampling ("dynamics") mode (see below). The spectral samplings are $0.065 \mathrm{~cm}^{-1}$ for the chemistry mode and $0.65 \mathrm{~cm}^{-1}$ for the dynamics mode. Other combinations of spectral and spatial resolution can be used, if desirable for a specific scientific objective. In the dynamics mode, the time saved by running the interferometer at a much shorter optical path difference (i.e. lower spectral resolution) is used for panning the line of sight from about $45^{\circ}$ to $135^{\circ}$ with respect to the aircraft flight direction. An illustration of the panning, which allows for tomographic applications, is given in the left panel of Fig. 4. The overlap of different viewing angles in the same air volume can be used for tomographic retrievals, also in the case of a linear flight pattern (left panel of Fig. 4). These tomographic capabilities can even be enhanced by choosing a closed flight pattern as illustrated in the right panel of Fig. 4 for a circle (Ungermann et al., 2010, 2011). The high spatial density of tangent points resulting from the large range of viewing angles in a closed-path tomography
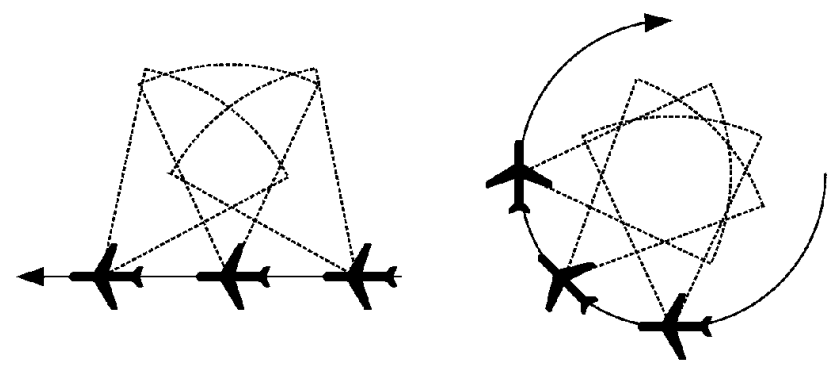

Figure 4. Flight patterns of GLORIA onboard HALO or M55Geophysica. The panning range of the instrument is illustrated by dashed lines. Line-of-sight (LOS) panning allows for tomographic measurements even during linear flights (left), since a fraction of the air volume covered is observed from different directions. The tomographic capabilities can be further enhanced by choosing a closed flight pattern like a circle (right).

is illustrated in Fig. 5. First results of a tomographic measurement of a fine filament of enhanced $\mathrm{HNO}_{3}$ values are presented in Sect. 3.2.

The GLORIA chemistry mode is optimised in terms of spectral instead of horizontal resolution. The high-spectral sampling of about $0.065 \mathrm{~cm}^{-1}$ allows for the retrieval of trace gases which cannot (or less reliably) be derived in the dynamics mode. The larger interferometer sweep time needed for one limb image at maximum spectral resolution results in a reduced along-track sampling while maintaining the same vertical sampling at a fixed azimuth angle. The chemistry mode is especially suited for the reconstruction of 2-D distributions (curtains) of a huge number of trace gases along the flight track rather than tomographically resolved 3-D temperature or trace gas fields. As an example, Fig. 6 shows measurements of ethane $\left(\mathrm{C}_{2} \mathrm{H}_{6}\right)$ retrieved from chemistry mode measurements on 18 September 2012 for a flight between the Maldives and Cyprus during the ESMVal campaign. $\mathrm{C}_{2} \mathrm{H}_{6}$ is a typical tracer for polluted air, being produced by biomass burning and fossil fuel production with a tropospheric lifetime of few months (Xiao et al., 2008). The enhancements of $\mathrm{C}_{2} \mathrm{H}_{6}$ in Fig. 6 point to transport of polluted air into the free troposphere and the UTLS either from local source or large-scale advection from the monsoon area.

\subsection{First tomographic observations}

The first tomographic observations took place during the TACTS and ESMVal aircraft campaign in summer/autumn 2012. Due to operational aircraft constraints, hexagons with a typical segment length of $200 \mathrm{~km}$ were chosen as closed paths instead of circles for enhanced tomographic applications. The high tangent point density results in a horizontal resolution of about $30 \mathrm{~km} \times 30 \mathrm{~km}$ for temperature structures and atmospheric trace species such as ozone, $\mathrm{HNO}_{3}$, CFC-11, and water vapour (Blank, 2013). Such a horizontal resolution represents an important prerequisite for major 


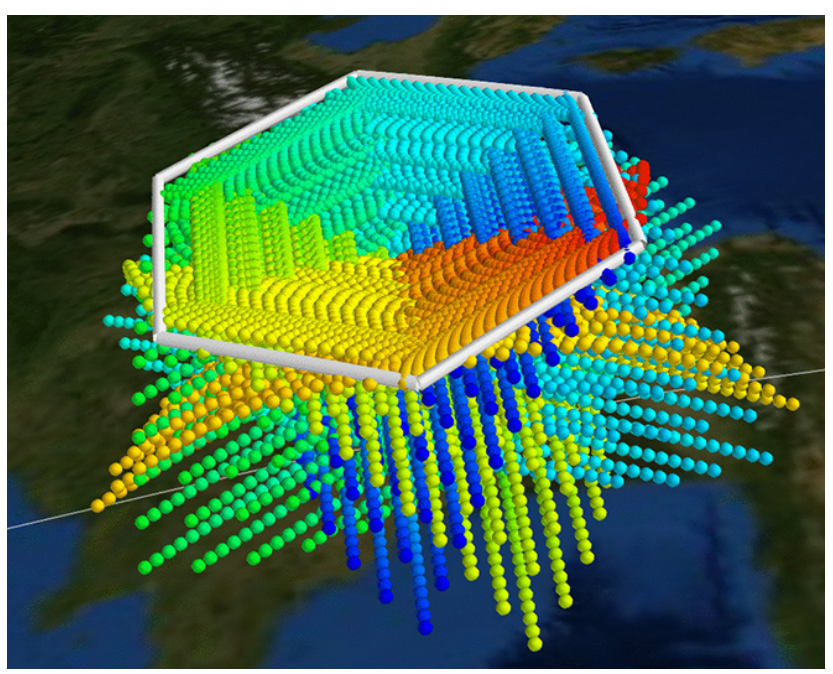

Figure 5. Visualisation of a hexagonal flight pattern and corresponding tangent points. Each colour corresponds to limb observations obtained for one flight segment. For example, red points correspond to measurements made during the first flight segment and blue points correspond to measurements made during the last flight segment. The tangent point density is highest in a $2-3 \mathrm{~km}$ thick layer below the flight level. For details see Ungermann et al. (2010).

contributions to the specific scientific questions outlined in Sect. 4.

Figure 7 shows the HALO flight pattern south of Cape Town (South Africa) for 12 September 2012 during the ESMVal campaign. GLORIA encountered a situation with highly variable trace gas fields resulting from a planetary wavebreaking event, which is indicated by a large northward displacement of polar air at $12 \mathrm{~km}$ altitude. Polar vortex air can be identified by large absolute values of potential vorticity. The HALO flight track including the position of the tomographic hexagon and indications of tangent point locations is also shown in Fig. 7. GLORIA observations in the tomographic volume confirm that this wave-breaking event was associated with pronounced small-scale trace gas filamentation. Figure 8 shows, in fact, the first three-dimensional tomographic observation of a small-scale filament of stratospheric air (enhanced $\mathrm{HNO}_{3}$ values), which is surrounded by tropospheric air. A more detailed description of these tomographic measurements and quantitative retrieval results, including the achievable vertical and horizontal resolution and error estimates, is given in the accompanying publication of Kaufmann et al. (2014). In the tomographic volume shown in Fig. 7, the instrument resolved a fine $\mathrm{HNO}_{3}$ filament. The spatial resolution achieved in this situation was about $300 \mathrm{~m}$ in the vertical direction and about $20 \mathrm{~km} \times 20 \mathrm{~km}$ horizontally.

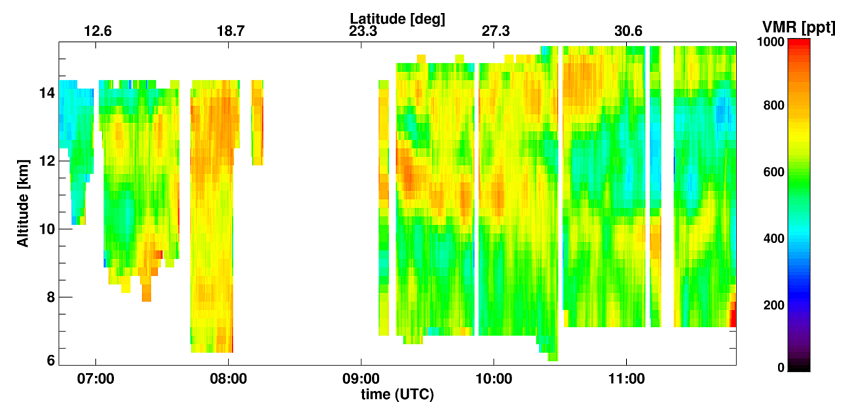

Figure 6. Distribution of ethane $\left(\mathrm{C}_{2} \mathrm{H}_{6}\right)$ derived from GLORIA chemistry mode measurements along the track of flight 18 September 2012 over the Arabian Sea and the Arabian Peninsula. The enhancements of ethane point to transport of polluted air into the free troposphere from local sources and suggest, along with trajectory calculations, large-scale advection of polluted air from the monsoon area.

\section{Specific scientific objectives}

\subsection{Composition of the extratropical UTLS}

The extratropical UTLS is part of the downwelling regime of the Brewer-Dobson (BD) circulation. Air in this region is composed of aged air masses, which have been transported downward from the deeper stratosphere by the BD circulation, and younger air masses of tropospheric origin. An overview on the processes influencing the extratropical UTLS is given by Gettelman et al. (2011). Some of the important features are illustrated in Fig. 9. The composition of the extratropical lowermost stratosphere (LMS) is strongly influenced by isentropic (quasi-horizontal) transport of air masses from the tropics. This poleward transport is related to Rossby wave breaking. It reverses its seasonality at altitudes above $420 \mathrm{~K}$ (e.g. Homeyer and Bowman, 2013). Above $420 \mathrm{~K}$, isentropic (quasi-horizontal) mixing of trace gases with steep mixing ratio gradients between the tropics and extratropics maximises during winter in the stratospheric surf zone (McIntyre and Palmer, 1983) and is related to structures from large-scale planetary tongues (streamers) to filaments of subtropical air that are mixed into the winter stratosphere (Randel et al., 1993; Riese et al., 1999b, 2002). Below $420 \mathrm{~K}$, quasi-horizontal transport and mixing of trace gases with steep mixing ratio gradients between the tropical troposphere and extratropical LMS (e.g. water vapour and ozone) maximises during summer and autumn (e.g. Ploeger et al., 2013). Associated intrusions of low-latitude air masses may propagate deep into the LMS (e.g. Pan et al., 2009; Vogel et al., 2011).

First observations during the HALO missions TACTS and ESMVal in summer/autumn 2012 demonstrate the capability of GLORIA to resolve small-scale transport structures related to wave-breaking events. Figure 8 shows a baroclinic filamentary structure originating from shallow tropopause 


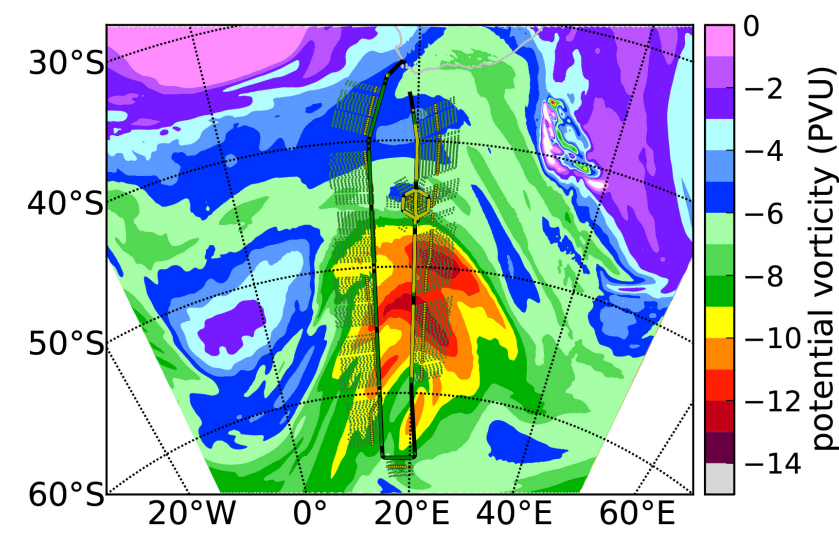

Figure 7. Meteorological situation during the ESMVal flight on 12 September 2012. Coloured areas indicate potential vorticity (PV) values at $12 \mathrm{~km}$ altitude. The flight path is shown by the coloured line. Operation phases in the dynamics mode and chemistry mode are shown in yellow and green, respectively. The tomographic measurement, indicated by the hexagon, was made in an area of strong wave activity as reflected in the PV field.

folds in the core of the jet stream and brought into the UTLS by a breaking Rossby wave. Dedicated studies of this quasihorizontal transport are planned for the Wave-driven ISentropic Exchange (WISE) campaign (HALO) in autumn 2017. Imaging the structure and composition of filaments, ideally measuring it at multiple times during its evolution, in combination with trajectory analysis of its genesis and further evolution will provide case studies to benchmark model simulations against.

\subsubsection{Extra-tropical transition layer and tropopause inversion layer}

The extratropical transition layer (ExTL), as illustrated in Fig. 9, is generated by bi-directional mixing across the tropopause (e.g. Fischer et al., 2000; Hoor et al., 2002; Krebsbach et al., 2006). The vertical depth of the ExTL is about $25 \mathrm{~K}$ in the LMS with respect to the local tropopause (Hoor et al., 2004). The layer is most pronounced during summer and exhibits large seasonal variability. The formation of the ExTL is a result of disturbances of the subtropical jet by large-scale wave activity (timescales of days to weeks) or transport from below, for example, by warm conveyor belts or deep convection (e.g. Anderson et al., 2012).

Analyses of airborne in situ observations (Kunz et al., 2009) and satellite observations (Hegglin et al., 2009) suggest a relation between the ExTL and the dynamical feature of the tropopause inversion layer (TIL). The TIL represents a vertically narrow region of strongly enhanced static stability directly above the extratropical tropopause (Birner et al., 2002, 2006; Wirth, 2003). Several mechanisms contributing to the formation of the TIL have been discussed such as effects of the residual circulation (Birner, 2010) or baroclinic wave-breaking events in the extratropics (Son and Polvani,

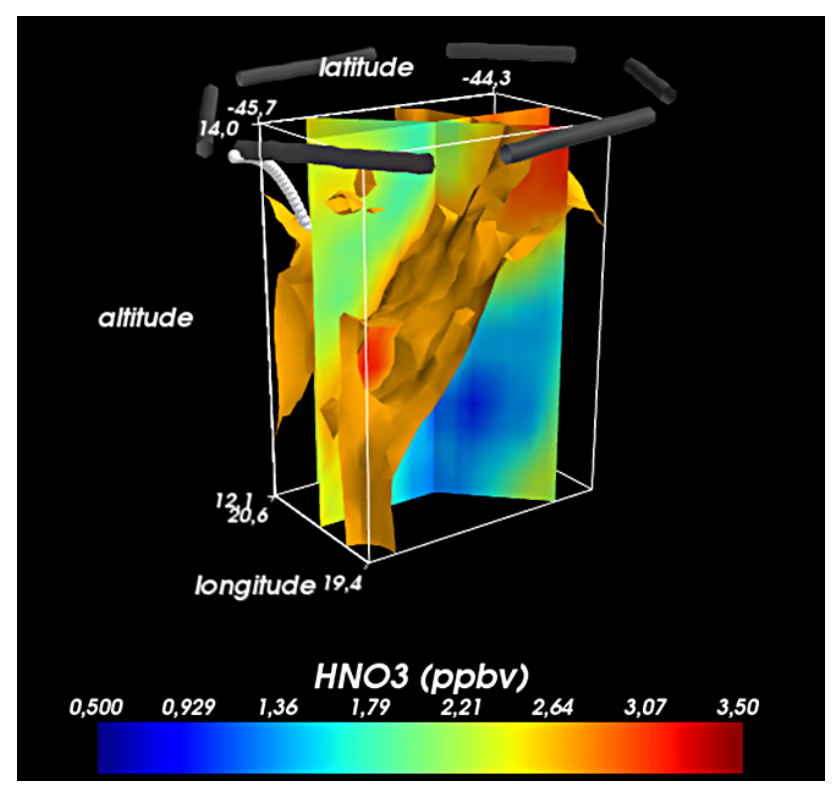

Figure 8. First tomographic observation of a three-dimensional small-scale structure during a HALO flight on 12 September 2012. The HALO flight track at about $14 \mathrm{~km}$ is indicated by dark grey bars, which form a hexagon. The geographical location of this hexagon is shown in Fig. 7. The tomographic measurement volume below the flight track extends down to about $12 \mathrm{~km}$. Individual tangent points are presented by small white spheres. The most prominent feature is a filament of stratospheric air (enhanced $\mathrm{HNO}_{3}$ values) that is surrounded by tropospheric air. The filament is illustrated by the 2.7 ppbv contour of enhanced $\mathrm{HNO}_{3}$ values. In addition, some cross sections of $\mathrm{HNO}_{3}$ values through the tomographic volume are displayed.

2007). Randel et al. (2007) suggest a radiation-controlled formation and maintenance of the TIL, mainly involving water vapour and ozone. The relative contributions of dynamics and radiation processes on the formation of the TIL is still a matter of debate. According to Kunz et al. (2009), a rather well-mixed ExTL appears to be a prerequisite for a radiationcontrolled formation of the TIL. It is, however, unclear to what extent the TIL, in turn, affects the spatial distribution of radiatively active species such as water vapour and ozone.

GLORIA will provide a unique combination of threedimensional high-resolution temperature measurements (static stability $\mathrm{N}^{2}$ ) and simultaneous measurements of water vapour, ozone, cirrus clouds, and tracers. In particular, information on static stability at a spatial resolution of $500 \mathrm{~m} \times 30 \mathrm{~km} \times 30 \mathrm{~km}$ will give new insight into the relationship of static stability and the spatial structures of radiatively active trace gases. Moreover, GLORIA remote-sensing data will be complemented during WISE by a comprehensive set of in situ observations, which provides detailed information on mixing processes based the tracer-tracer correlation technique and corresponding model simulations (e.g. Vogel et al., 2011). 


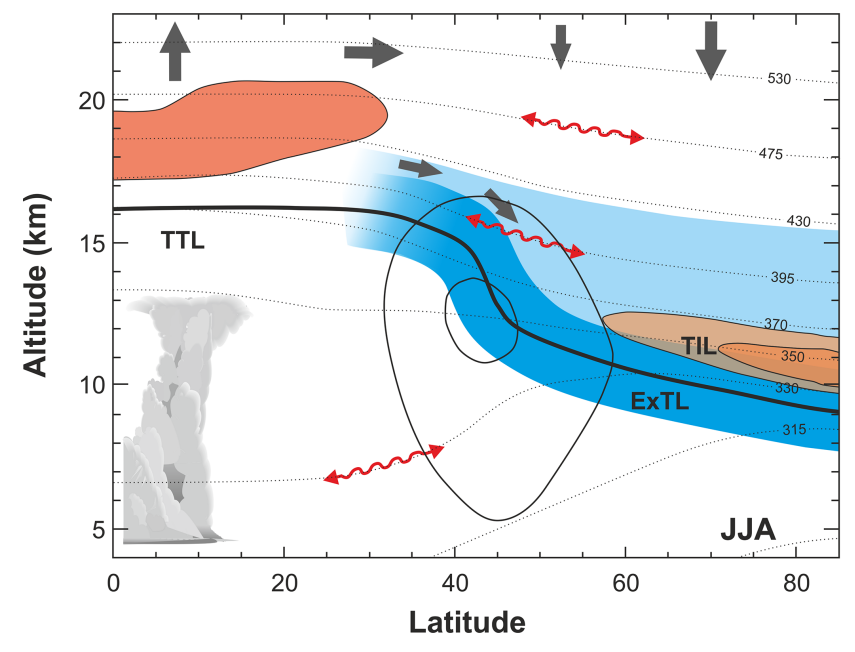

Figure 9. Illustration of dynamical and chemical structure of the UTLS for Northern Hemisphere summer (JJA) conditions (adapted from Fig. $2 b$ of Gettelman et al., 2011). The thick black line represents the thermal tropopause for the period 2002 to 2008. Dotted lines are isentropes. Black solid contours indicate the location of the subtropical jet (STJ). Areas of enhanced static stability (tropopause inversion layer) are indicated by red shading. The extratropical transition layer (ExTL) is represented in dark blue and the lowermost stratosphere (LMS) above the ExTL in light blue.

\subsubsection{Quasi-horizontal transport above the ExTL}

The composition of the Northern Hemisphere LMS is strongly influenced by Rossby wave breaking, which occurs mainly over the Northern Atlantic and Pacific during summer and autumn (e.g. Postel and Hitchman, 1999; Homeyer and Bowman, 2013). Ploeger et al. (2013) showed that in the vicinity of the subtropics, quasi-horizontal (isentropic) transport of water vapour in the upper part of the LMS (around $400 \mathrm{~K}$ ) is dominated by the shallow branch of the residual circulation. At middle to high latitudes, large-scale eddy mixing becomes most important. The dominant influence of horizontal transport extends up to about $450 \mathrm{~K}$ during summer and autumn. It is reflected in a clear anti-correlation between water vapour and ozone in both Microwave Limb Sounder (MLS) observations (Livesey et al., 2006) and simulations by the Chemical Lagrangian Model of the Stratosphere (CLaMS). However, the study of Ploeger et al. (2013) also revealed significant differences between the observed and simulated anti-correlations that can be attributed to the finite resolution of the satellite observations and imperfections of the transport simulated by CLaMS.

GLORIA observations with high spatial resolution and good spatial coverage can be used to test the capability of models like CLaMS to capture medium- and smallscale transport structures (e.g. filaments) and associated anticorrelations between water vapour and ozone. In addition, we will investigate air masses with enhanced amounts of water vapour and pollutants in the LMS, originating from convective uplift by the Asian monsoon (see Ploeger et al., 2013). Such air masses have been detected by in situ measurements onboard HALO during TACTS and could be traced back to the Asian monsoon by CLaMS simulations and trajectory calculations (Vogel et al., 2014). The chemistry mode of GLORIA is capable of detecting a range of pollutants, thereby being ideally capable of identifying and distinguishing, in combination with backward trajectories, between different sources of pollution.

\subsubsection{Occurrence of subvisible cirrus clouds in the LMS}

Transport of water vapour also plays an important role for the formation of cirrus clouds. Presently, the importance of various water vapour pathways into the LMS on subvisible cirrus formation is controversially being discussed (e.g. Dessler, 2009; Pan and Munchak, 2011). Ground-based cloud observations from mid-latitude lidar stations show occasionally subvisible cirrus cloud (SVC) events at and above the tropopause (Keckhut et al., 2005). Many of them coincide with observations of a secondary tropopause (Noel and Haeffelin, 2007). These events may be caused by isentropic water vapour transport from the subtropics associated with Rossby wave breaking (e.g. Eixmann et al., 2010). Infrared limb observations of cirrus clouds during the CRISTA-2 mission in 1997 also suggest frequent cirrus events around the mid-latitude tropopause (Spang et al., 2002).

Measurements during WISE will cover the North Atlantic to Scandinavia region, which is a preferential region for subvisible cirrus clouds in the LMS (Spang et al., 2014). The high occurrence rate in this region is a result of enhanced Rossby-wave activity (see above) and the occurrence of warm conveyor belts, which appear to trigger cirrus cloud formation in the upper troposphere (Spichtinger et al., 2005).

An important issue for the detection of subvisible cirrus clouds is the sensor sensitivity. Passive nadir sounders substantially underestimate the occurrence of SVCs in comparison to IR limb sounders (e.g. Spang et al., 2012). Even active lidars are less sensitive and may underestimate the occurrence frequency of SVCs. For example, the IWC threshold for CALIOP lidar nadir-observations is in the range of 0.1 to $4 \times 10^{-3} \mathrm{~g} \mathrm{~m}^{-3}$, while IWCs of about $10^{-6} \mathrm{~g} \mathrm{~m}^{-3}$ are detectable by infrared limb viewing for a cirrus cloud layer with a horizontal extent of about $30 \mathrm{~km}$ or larger (Spang et al., 2012).

The high sensitivity of IR limb sounding with respect to vertically very thin cloud layers was already demonstrated by Spang et al. (2008) based on CRISTA-NF observations. In addition to high sensitivity, GLORIA provides a unique view on the three-dimensional structure of subvisible cirrus including their position with respect to the thermal tropopause. The accurate determination of the position of SVCs with respect to the thermal tropopause benefits from the very narrow vertical field of view (FOV) and dense vertical sampling, 
which result in a vertical resolution of cloud signatures of about $150 \mathrm{~m}$ at $10 \mathrm{~km}$ tangent altitude $(5 \mathrm{~km}$ below the flight altitude).

\subsubsection{Influence of the Asian summer monsoon on UTLS composition}

The Asian monsoon circulation is an important pathway for air masses from the boundary layer into the tropical upper troposphere and tropical tropopause layer (TTL). This transport also influences the composition of the ascending branch of the BD circulation (Randel et al., 2010) as well as isentropic (quasi-horizontal) transport of water vapour and tropospheric pollutants from the tropics into the extratropical LMS (Ploeger et al., 2013).

An important part of the Asian monsoon circulation is an anticyclone in the UT extending from Asia to the Middle East (Park et al., 2007). This anticyclone confines a region of persistent enhanced pollution caused by rapid vertical transport of polluted air from, e.g. southern China, India, and Indonesia by deep convection. Along the eastern edge of the monsoon anticyclone, air masses are transported equatorwards and finally affect the trace gas composition of the TTL and the ascending branch of the BD circulation (Konopka et al., 2009, 2010; Ploeger et al., 2012).

Along the western flank of the Asian monsoon anticyclone, air is transported into the extratropical LMS (Ploeger et al., 2013). An illustration of associated transport structures is given in Fig. 10 based on ozone concentrations simulated by CLaMS. Quantitative analyses of the associated transport and mixing processes require two- and three-dimensional observations of multiple trace gases with the highest achievable resolution, complemented by detailed (1-D) in situ observations. GLORIA will provide such observations onboard M55-Geophysica during the Stratospheric and upper tropospheric processes for better Climate predictions (StratoClim) tropical aircraft campaign (FP7) in summer 2015.

\subsection{Evolution of the polar stratosphere in a changing climate}

The polar stratosphere is important for the evolution of the global ozone layer and for the climate system. The amounts of ozone-depleting substances in the stratosphere are expected to decrease in the next decades due to the restrictions following the Montreal Protocol. However, lower Arctic stratospheric temperatures, possibly resulting from radiative effects of increased greenhouse gas concentrations, would lead to a more frequent appearance of polar stratospheric clouds (PSCs), extended ozone depletion and a delay in global ozone recovery (e.g. Sinnhuber et al., 2011; WMO, 2011). Furthermore, chemically processed air from the polar vortex can enter the mid-latitude LMS via fast transport processes and can affect the local chemical composition and radiation budget (e.g. Werner et al., 2010). A detailed

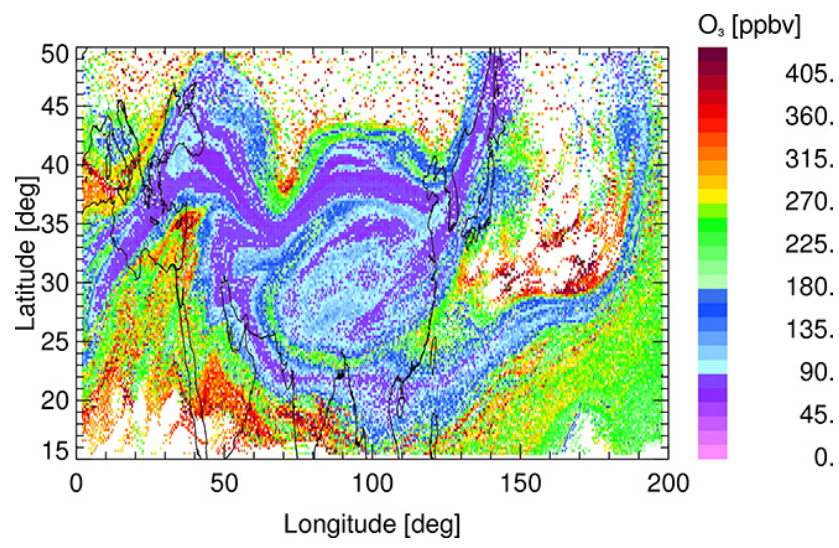

Figure 10. Ozone distribution in the upper part of the Asian monsoon anticyclone (about $18 \mathrm{~km}$ ) for 9 August 2003 as simulated by the CLaMS model with a horizontal resolution of around $25 \mathrm{~km}$. The Asian monsoon has a strong influence on the composition of the tropical tropopause region (TTL). "Young" tropospheric air (low ozone) results from fast convective upward transport in the centre of the Asian monsoon. Quasi-horizontal mixing of older extratropical stratospheric air (high ozone values) into the TTL occurs at the edge of the highly variable anticyclone.

understanding of these processes is necessary to allow reliable estimations of the evolution of the ozone layer and the role of the polar stratosphere in the future climate.

Previous studies utilising the balloon-borne MIPAS instrument have shown that accurate observations of the budgets of $\mathrm{NO}_{\mathrm{y}}$ and chlorine species (e.g. Wiegele et al., 2009; Wetzel et al., 2010) as well as important photochemical processes (Wetzel et al., 2012) are possible using infrared limb observations. Measurements by MIPAS-STR and CRISTA-NF have shown that vortex filaments can be distinguished from mid-latitude air masses using this technique (e.g. Ungermann et al., 2012; Woiwode et al., 2012) and allow for detailed studies of stratospheric dynamics in combination with highresolution chemistry transport modelling (Kalicinsky et al., 2013).

During the Polar Stratosphere in a Changing Climate (POLSTRACC) campaign (HALO) in winter/spring 2015/2016, GLORIA will provide spatially highly resolved observations allowing detailed investigations of key processes such as $\mathrm{NO}_{\mathrm{y}}$ redistribution following denitrification, PSC occurrence and composition, and chlorine activation and de-activation. Furthermore, the measurements will allow for the study of transport processes between polar and lower latitudes as well as between the LMS and the UT.

\subsection{Gravity wave observations}

Surface climate is influenced by both radiative and dynamical processes in the atmosphere. In particular, there is growing evidence that dynamical couplings in the stratospheretroposphere system have a significant impact on regional 
weather patterns and climate, mainly through changes of the Northern and Southern Hemisphere annular modes (NAM and SAM, respectively). Predicted changes of the strength of the stratospheric BD circulation may also modify tropospheric weather patterns. Small-scale gravity waves (GWs) play an important role in these atmospheric couplings but also represent a major source of uncertainty (Sigmond and Scinocca, 2010). Parameterised gravity wave drag may also account for much of the potential future trend of the BrewerDobson circulation in atmospheric models (e.g. McLandress and Shepherd, 2009; Butchart et al., 2010). However, these effects are far from being well understood. The largest uncertainties in atmospheric wave dynamics are associated with gravity waves, their sources, their propagation, and the representation of their characteristics in global models (Alexander et al., 2010).

Infrared limb sounding provides valuable information on atmospheric gravity waves (e.g. Fetzer and Gille, 1994; Eckermann and Preusse, 1999; Ern et al., 2006, 2011; Preusse et al., 2009a; Geller et al., 2013). High-resolution 3 -D temperature observations $(300 \mathrm{~m} \times 30 \mathrm{~km} \times 30 \mathrm{~km})$ by GLORIA can be used to determine gravity wave temperature amplitudes and associated horizontal and vertical wavelength (wave vector) simultaneously. From these quantities direction-resolved momentum flux can be derived and gravity waves can be traced back to their sources (e.g. Ern et al., 2004; Preusse et al., 2009b, 2012). This approach will provide important constraints for gravity wave models and parametrisations. Corresponding observations are planned for the HALO campaign Gravity Wave Life Cycle (GWLCycle), which is combined with POLSTRACC and will take place in winter/spring 2015/2016. GLORIA temperature observations will be combined with 3-D wind speed measurements to test the validity of the gravity wave polarisation relation (linear theory), which provides the basis for the determination of direction-resolved momentum flux from three-dimensional temperature fields.

\section{Conclusions}

In the past, infrared limb sounding provided a wealth of data for investigations of the composition and dynamic structure of the middle atmosphere, in particular on a large scale. A new focus is the region of the upper troposphere/lower stratosphere (UTLS) due to its importance for the climate system. Presently, there is an observational gap between synoptic-scale structures in UTLS composition resolved by satellites and small-scale variability resolved by airborne in situ instruments. Filling this gap is essential, because smalland meso-scale physical and chemical processes (e.g. trace gas exchange, clouds, or gravity waves) play a crucial role for the composition and dynamic structure of the UTLS.

The Gimballed Limb Observer for Radiance Imaging (GLORIA) instrument addresses the observational gap in the
UTLS by providing two- and three-dimensional observations of temperature structures, trace gases, and subvisible cirrus clouds with unprecedented spatial resolution. The vertical resolution of the observations is up to $300 \mathrm{~m}$ for both dynamics and chemistry mode. Novel tomographic observations provide a horizontal resolution of about $30 \mathrm{~km} \times 30 \mathrm{~km}$ for temperature structures and most of the observable trace species. GLORIA therefore provides adequate spatial resolution for improved process studies in the UTLS.

Important scientific questions for GLORIA concern the interaction of the extratropical transition layer (ExTL) with the tropopause inversion layer (TIL) as well as isentropic (quasihorizontal) exchange of air masses between the tropical UT and the extratropical LMS. The influence of isentropic water vapour transport from the tropics on the occurrence of subvisible cirrus clouds in the LMS can be investigated on the basis of GLORIA's high sensitivity to optically thin subvisible cirrus clouds. Furthermore, GLORIA measurements will allow for the study of ozone and climate-relevant processes in the Arctic UTLS as well as exchange processes between vortex and lower-latitude air and between the LMS and UT in detail. Besides composition measurements, GLORIA will also enhance our knowledge on gravity wave processes by providing direction-resolved momentum flux and, thus, deliver important constraints for gravity wave representations in global models.

Acknowledgements. We thank all members of the GLORIA instrument team for their large efforts in developing the first IR limb imager. The GLORIA hardware was mainly funded by the Helmholtz Association of German Research Centres through several large investment funds. The development of the retrieval algorithms was supported by the Deutsche Forschungsgemeinschaft through the RASSGLO project. We also wish to thank Lars Hoffmann, who developed the JURASSIC-1 forward model and significantly contributed to several ESA studies of the limbimaging concept. Many scientist involved in TACTS, ESMVal, POLSTRACC, GW-LCycle, and WISE contributed to fruitful discussions of the GLORIA science objectives. We thank the CLaMS team for assisting the flight planning by CLaMS model forecasts supported by German Research Foundation (DFG) under the project LASSO (HALO-SPP 1294/GR 3786). The operational implementation of the first tomographic flights was supported by Harald Bönisch and Andreas Engel, who coordinated TACTS. We also gratefully acknowledge the funding of the ESMVal flight hours by DLR and the coordination of ESMVal by Hans Schlager.

The service charges for this open access publication have been covered by a Research Centre of the Helmholtz Association.

Edited by: C. von Savigny 


\section{References}

Alexander, M. J., Geller, M., McLandress, C., Polavarapu, S., Preusse, P., Sassi, F., Sato, K., Eckermann, S., Ern, M., Hertzog, A., Kawatani, Y., Pulido, M., Shaw, T. A., Sigmond, M., Vincent, R., and Watanabe, S.: Recent developments in gravitywave effects in climate models and the global distribution of gravity-wave momentum flux from observations and models, Q. J. Roy. Meteorol. Soc., 136, 1103-1124, doi:10.1002/qj.637, 2010.

Anderson, J. G., Wilmouth, D. M., Smith, J. B., and Sayres, D. S.: UV dosage levels in summer: increased risk of ozone loss from convectively injected water vapor, Science, 337, 835-839, doi:10.1126/science.1222978, 2012.

Aref, H: Stirring by chaotic advection, J. Fluid Mech., 143, 1-21, doi:10.1017/S0022112084001233, 1984.

Bingham, G. E., Zhou, D. K., Bartschi, B. Y., Anderson, G. P., Smith, D. R., Chetwynd, J. H., and Nadile, R. M.: Cryogenic Infrared Radiance Instrumentation for Shuttle (CIRRIS 1A) Earth limb spectral measurements, calibration, and atmospheric $\mathrm{O}_{3}$, $\mathrm{HNO}_{3}$, CFC-12, and CFC-11 profile retrieval, J. Geophys. Res.Atmos., 102, 3547-3558, 1997.

Birner, T.: Residual circulation and tropopause structure, J. Atmos. Sci., 67, 2582-2600, doi:10.1175/2010JAS3287.1, 2010.

Birner, T., Dörnbrack, A., and Schumann, U.: How sharp is the tropopause at midlatitudes?, Geophys. Res. Lett., 29, 1700, doi:10.1029/2002GL015142, 2002.

Birner, T., Sankey, D., and Shepherd, T. G.: The tropopause inversion layer in models and analyses, Geophys. Res. Lett., 33, L14808, doi:10.1029/2006GL026549, 2006.

Blank, J.: Tomographic retrieval of atmospheric trace gases observed by GLORIA, Dissertation, Universität Wuppertal, 2013.

Butchart, N., Cionni, I., Eyring, V., Shepherd, T. G., Waugh, D. W., Akiyoshi, H., Austin, J., Bruehl, C., Chipperfield, M. P., Cordero, E., Dameris, M., Deckert, R., Dhomse, S., Frith, S. M., Garcia, R. R., Gettelman, A., Giorgetta, M. A., Kinnison, D. E., Li, F., Mancini, E., McLandress, C., Pawson, S., Pitari, G., Plummer, D. A., Rozanov, E., Sassi, F., Scinocca, J. F., Shibata, K., Steil, B., and Tian, W.: Chemistryclimate model simulations of twenty-first century stratospheric climate and circulation changes, J. Climate, 23, 5349-5374, doi:10.1175/2010JCLI3404.1, 2010.

Dessler, A. E.: Clouds and water vapor in the Northern Hemisphere summertime stratosphere, J. Geophys. Res.-Atmos., 114, D00H9, doi:10.1029/2009JD012075, 2009.

Drummond, J. R., Houghton, J. T., Peskett, G. D., Rodgers, C. D., Wale, M. J., Whitney, J., and Williamson, E. J.: The stratospheric and mesospheric sounder on Nimbus 7, Philos. T. Roy. Soc. A, 296, 219-241, doi:10.1098/rsta.1980.0166, 1980.

Eckermann, S. D. and Preusse, P.: Global measurements of stratospheric mountain waves from space, Science, 286, 1534-1537, 1999.

Eixmann, R., Peters, D. H. W., Zuelicke, C., Gerding, M., and Doernbrack, A.: On the upper tropospheric formation and occurrence of high and thin cirrus clouds during anticyclonic poleward Rossby wave breaking events, Tellus, 62, 228-242, doi:10.1111/j.1600-0870.2010.00437.x, 2010.

Ern, M., Preusse, P., Alexander, M. J., and Warner, C. D.: Absolute values of gravity wave momentum flux derived from satellite data, J. Geophys. Res.-Atmos., 109, D20103, doi:10.1029/2004JD004752, 2004.

Ern, M., Preusse, P., and Warner, C. D.: Some experimental constraints for spectral parameters used in the Warner and McIntyre gravity wave parameterization scheme, Atmos. Chem. Phys., 6, 4361-4381, doi:10.5194/acp-6-4361-2006, 2006.

Ern, M., Preusse, P., Gille, J. C., Hepplewhite, C. L., Mlynczak, M. G., Russell III, J. M., and Riese, M.: Implications for atmospheric dynamics derived from global observations of gravity wave momentum flux in stratosphere and mesosphere, J. Geophys. Res.-Atmos., 116, D19107, doi:10.1029/2011JD015821, 2011.

ESA: Report for Mission Selection: PREMIER, Vol. SP-1324/3, ESA Communication Production Office, Noordwijk, the Netherlands, 2012.

Fetzer, E. J. and Gille, J. C.: Gravity wave variance in LIMS temperatures, Part I: Variability and comparison with background winds, J. Atmos. Sci., 51, 2461-2483, 1994.

Fischer, H. and Oelhaf, H.: Remote sensing of vertical profiles of atmospheric trace constituents with MIPAS limb-emission spectrometers, Appl. Optics, 35, 2787-2796, 1996.

Fischer, H., Wienhold, F., Hoor, P., Bujok, O., Schiller, C., Siegmund, P., Ambaum, M., Scheeren, H., and Lelieveld, J.: Tracer correlations in the northern high latitude lowermost stratosphere: influence of cross-tropopause mass exchange, Geophys. Res. Lett., 27, 97-100, doi:10.1029/1999GL010879, 2000.

Fischer, H., Birk, M., Blom, C., Carli, B., Carlotti, M., von Clarmann, T., Delbouille, L., Dudhia, A., Ehhalt, D., Endemann, M., Flaud, J. M., Gessner, R., Kleinert, A., Koopman, R., Langen, J., López-Puertas, M., Mosner, P., Nett, H., Oelhaf, H., Perron, G., Remedios, J., Ridolfi, M., Stiller, G., and Zander, R.: MIPAS: an instrument for atmospheric and climate research, Atmos. Chem. Phys., 8, 2151-2188, doi:10.5194/acp-8-2151-2008, 2008.

Friedl-Vallon, F., Maucher, G., Seefeldner, M., Trieschmann, O., Kleinert, A., Lengel, A., Keim, C., Oelhaf, H., and Fischer, H.: Design and characterization of the balloon-borne michelson interferometer for passive atmospheric sounding (MIPAS-B2), Appl. Optics, 43, 3335-3355, doi:10.1364/AO.43.003335, 2004.

Friedl-Vallon, F., Riese, M., Maucher, G., Lengel, A., Hase, F., Preusse, P., and Spang, R.: Instrument concept and preliminary performance analysis of GLORIA, Adv. Space Res., 37, 22872291, doi:10.1016/j.asr.2005.07.075, 2006.

Friedl-Vallon, F., Gulde, T., Hase, F., Kleinert, A., Kulessa, T., Maucher, G., Neubert, T., Olschewski, F., Piesch, C., Preusse, P., Rongen, H., Sartorius, C., Schneider, H., Schönfeld, A., Tan, V., Bayer, N., Blank, J., Dapp, R., Ebersoldt, A., Fischer, H., Graf, F., Guggenmoser, T., Höpfner, M., Kaufmann, M., Kretschmer, E., Latzko, T., Nordmeyer, H., Oelhaf, H., Orphal, J., Riese, M., Schardt, G., Schillings, J., Sha, M. K., Suminska-Ebersoldt, O., and Ungermann, J.: Instrument concept of the imaging Fourier transform spectrometer GLORIA, Atmos. Meas. Tech. Discuss., 7, 2301-2337, doi:10.5194/amtd-7-2301-2014, 2014.

Geller, M. A., Alexander, M. J., Love, P. T., Bacmeister, J., Ern, M., Hertzog, A., Manzini, E., Preusse, P., Sato, K., Scaife, A. A., and Zhou, T.: A comparison between gravity wave momentum fluxes in observations and climate models, J. Climate, 26, 6383-6405, doi:10.1175/JCLI-D-12-00545.1, 2013.

Gettelman, A., Hoor, P., Pan, L. L., Randel, W. J., Hegglin, M. I., and Birner, T.: The extra tropical upper tropo- 
sphere and lower stratosphere, Rev. Geophys., 49, RG3003, doi:10.1029/2011RG000355, 2011.

Gille, J. C. and Russel III, J. M.: The Limb Infrared Monitor of the stratosphere: experiment description, performance, and results, J. Geophys. Res.-Atmos., 89, 5125-5140, doi:10.1029/JD089iD04p05125, 1984.

Gille, J. C., Barnett, J., Arter, P., Barker, M., Bernath, P., Boone, C., Cavanaugh, C., Chow, J., Coffey, M., Craft, J., Craig, C., Dials, M., Dean, V., Eden, T., Edwards, D. P., Francis, G., Halvorson, C., Harvey, L., Hepplewhite, C., Khosravi, R., Kinnison, D., Krinsky, C., Lambert, A., Lee, H., Lyjak, L., Loh, J., Mankin, W., Massie, S., McInerney, J., Moorhouse, J., Nardi, B., Packman, D., Randall, C., Reburn, J., Rudolf, W., Schwartz, M., Serafin, J., Stone, K., Torpy, B., Walker, K., Waterfall, A., Watkins, R., Whitney, J., Woodard, D., and Young, G.: The highresolution dynamics limb sounder: experiment overview, recovery, and validation of initial temperature data, J. Geophys. Res.Atmos., 113, D16S43, doi:10.1029/2007JD008824, 2008.

Grossmann, K. U., Offermann, D., Gusev, O., Oberheide, J., Riese, M., and Spang, R.: The CRISTA-2 mission, J. Geophys. Res.-Atmos., 107, 8173, doi:10.1029/2001JD000667, 2002.

Hegglin, M. I., Boone, C. D., Manney, G. L., and Walker, K. A.: A global view of the extratropical tropopause transition layer from Atmospheric Chemistry Experiment Fourier Transform Spectrometer $\mathrm{O}_{3}, \mathrm{H}_{2} \mathrm{O}$, and CO, J. Geophys. Res.-Atmos., 114, D00B11, doi:10.1029/2008JD009984, 2009.

Hoffmann, L., Weigel, K., Spang, R., Schroeder, S., Arndt, K., Lehmann, C., Kaufmann, M., Ern, M., Preusse, P., Stroh, F., and Riese, M.: CRISTA-NF measurements of water vapor during the SCOUT-O $_{3}$ Tropical Aircraft Campaign, Adv. Space Res., 43, 74-81, doi:10.1016/j.asr.2008.03.018, 2009.

Homeyer, C. R. and Bowman, K. P.: Rossby wave breaking and transport between the tropics and extratropics above the subtropical jet, J. Atmos. Sci., 70, 607-626, doi:10.1175/JAS-D-120198.1, 2013.

Hoor, P., Fischer, H., Lange, L., Lelieveld, J., and Brunner, D.: Seasonal variations of a mixing layer in the lowermost stratosphere as identified by the $\mathrm{CO}-\mathrm{O}_{3}$ correlation from in situ measurements, J. Geophys. Res.-Atmos., 107, 4004, doi:10.1029/2000JD000289, 2002.

Hoor, P., Gurk, C., Brunner, D., Hegglin, M. I., Wernli, H., and Fischer, H.: Seasonality and extent of extratropical TST derived from in-situ CO measurements during SPURT, Atmos. Chem. Phys., 4, 1427-1442, doi:10.5194/acp-4-1427-2004, 2004.

Kalicinsky, C., Grooß, J.-U., Günther, G., Ungermann, J., Blank, J., Höfer, S., Hoffmann, L., Knieling, P., Olschewski, F., Spang, R., Stroh, F., and Riese, M.: Observations of filamentary structures near the vortex edge in the Arctic winter lower stratosphere, Atmos. Chem. Phys., 13, 10859-10871, doi:10.5194/acp-1310859-2013, 2013.

Kaufmann, M., Blank, J., Guggenmoser, T., Ungermann, J., Engel, A., Ern, M., Friedl-Vallon, F., Gerber, D., Grooss, J. U., Guenther, G., Höpfner, M., Kleinert, A., Latzko, Th., Maucher, G., Neubert, T., Nordmeyer, H., Oelhaf, H., Olschewski, F., Orphal, J., Preusse, P., Schlager, H., Schneider, H., Schuettemeyer, D., Stroh, F., Suminska-Ebersoldt, O., Vogel, B., Volk, C. M., Woiwode, W., and Riese, M.: Retrieval of three-dimensional small scale structures in upper tropospheric/lower stratospheric com- position as measured by GLORIA, Atmos. Meas. Tech. Discuss., 7, 4229-4274, doi:10.5194/amtd-7-4229-2014, 2014.

Keckhut, P., Hauchecorne, A., Bekki, S., Colette, A., David, C., and Jumelet, J.: Indications of thin cirrus clouds in the stratosphere at mid-latitudes, Atmos. Chem. Phys., 5, 3407-3414, doi:10.5194/acp-5-3407-2005, 2005.

Keim, C., Liu, G. Y., Blom, C. E., Fischer, H., Gulde, T., Höpfner, M., Piesch, C., Ravegnani, F., Roiger, A., Schlager, H., and Sitnikov, N.: Vertical profile of peroxyacetyl nitrate (PAN) from MIPAS-STR measurements over Brazil in February 2005 and its contribution to tropical UT NO $\mathrm{N}_{\mathrm{y}}$ partitioning, Atmos. Chem. Phys., 8, 4891-4902, doi:10.5194/acp-8-4891-2008, 2008.

Kleinert, A., Friedl-Vallon, F., Guggenmoser, T., Höpfner, M., Neubert, T., Ribalda, R., Sha, M. K., Ungermann, J., Blank, J., Ebersoldt, A., Kretschmer, E., Latzko, T., Oelhaf, H., Olschewski, F., and Preusse, P.: Level 0 to 1 processing of the imaging Fourier transform spectrometer GLORIA: generation of radiometrically and spectrally calibrated spectra, Atmos. Meas. Tech. Discuss., 7, 2827-2878, doi:10.5194/amtd-7-2827-2014, 2014.

Konopka, P., Grooß, J.-U., Plöger, F., and Müller, R.: Annual cycle of horizontal in-mixing into the lower tropical stratosphere, J. Geophys. Res.-Atmos., 114, 148-227, doi:10.1029/2009JD011955, 2009.

Konopka, P., Grooß, J.-U., Günther, G., Ploeger, F., Pommrich, R., Müller, R., and Livesey, N.: Annual cycle of ozone at and above the tropical tropopause: observations versus simulations with the Chemical Lagrangian Model of the Stratosphere (CLaMS), Atmos. Chem. Phys., 10, 121-132, doi:10.5194/acp-10-121-2010, 2010.

Krebsbach, M., Schiller, C., Brunner, D., Günther, G., Hegglin, M. I., Mottaghy, D., Riese, M., Spelten, N., and Wernli, H.: Seasonal cycles and variability of $\mathrm{O}_{3}$ and $\mathrm{H}_{2} \mathrm{O}$ in the UT/LMS during SPURT, Atmos. Chem. Phys., 6, 109-125, doi:10.5194/acp-6-109-2006, 2006.

Kullmann, A., Riese, M., Olschewski, F., Stroh, F., and Grossmann, K. U.: Cryogenic Infrared Spectrometers and Telescopes for the Atmosphere - New Frontiers, in: Proc. SPIE, Vol. 5570, 423-432, doi:10.1117/12.564856, 2004.

Kunz, A., Konopka, P., Müller, R., Pan, L. L., Schiller, C., and Rohrer, F.: High static stability in the mixing layer above the extratropical tropopause, J. Geophys. Res.-Atmos., 114, D16305, doi:10.1029/2009JD011840, 2009.

Livesey, N., Van Snyder, W., Read, W., and Wagner, P.: Retrieval algorithms for the EOS Microwave limb sounder (MLS), IEEE T. Geosci. Remote, 44, 1144-1155, doi:10.1109/TGRS.2006.872327, 2006.

McIntyre, M. E. and Palmer, T. N.: Breaking planetary waves in the stratosphere, Nature, 305, 593-600, doi:10.1038/305593a0, 1983.

McLandress, C. and Shepherd, T. G.: Simulated anthropogenic changes in the Brewer-Dobson circulation, including its extension to high latitudes, J. Climate, 22, 1516-1540, doi:10.1175/2008JCLI2679.1, 2009.

Noel, V. and Haeffelin, M.: Midlatitude cirrus clouds and multiple tropopauses from a 2002-2006 climatology over the SIRTA observatory, J. Geophys. Res.-Atmos., 112, D13206, doi:10.1029/2006JD007753, 2007.

Offermann, D., Grossmann, K.-U., Barthol, P., Knieling, P., Riese, M., and Trant, R.: Cryogenic Infrared Spectrometers 
and Telescopes for the Atmosphere (CRISTA) experiment and middle atmosphere variability, J. Geophys. Res.-Atmos., 104, 16311-16325, doi:10.1029/1998JD100047, 1999.

Pan, L. L. and Munchak, L. A.: Relationship of cloud top to the tropopause and jet structure from CALIPSO data, J. Geophys. Res.-Atmos., 116, D12201, doi:10.1029/2010JD015462, 2011.

Pan, L. L., Randel, W. J., Gille, J. C., Hall, W. D., Nardi, B., Massie, S., Yudin, V., Khosravi, R., Konopka, P., and Tarasick, D.: Tropospheric intrusions associated with the secondary tropopause, J. Geophys. Res.-Atmos., 114, D10302, doi:10.1029/2008JD011374, 2009.

Park, M., Randel, W. J., Gettelman, A., Massie, S. T., and Jiang, J. H.: Transport above the Asian summer monsoon anticyclone inferred from Aura Microwave Limb Sounder tracers, J. Geophys. Res.-Atmos., 112, D16309, doi:10.1029/2006JD008294, 2007.

Pierce, R. B. and Fairlie, T. D. A.: Chaotic advection in the stratosphere: Implications for the dispersal of chemically perturbed air from the polar vortex, J. Geophys. Res., 98, 18589-18595, doi:10.1029/93JD01619, 1993.

Piesch, C., Gulde, T., Sartorius, C., Friedl-Vallon, F., Seefeldner, M., Wölfel, M., Blom, C., and Fischer, H.: Design of a MIPAS Instrument for High-Altitude Aircraft, in: Proc. of the Second Internat. Airborne Remote Sensing Conference and Exhibition, Vol. II, Ann Arbor, MI, 199-208, 1996.

Ploeger, F., Konopka, P., Müller, R., Fueglistaler, S., Schmidt, T., Manners, J. C., Grooss, J.-U., Günther, G., Forster, P. M., and Riese, M.: Horizontal transport affecting trace gas seasonality in the Tropical Tropopause Layer (TTL), J. Geophys. Res.-Atmos., 117, D09303, doi:10.1029/2011JD017267, 2012.

Ploeger, F., Günther, G., Konopka, P., Fueglistaler, S., Müller, R., Hoppe, C., Kunz, A., Spang, R., Grooss, J. U., and Riese, M.: Horizontal water vapor transport in the lower stratosphere from subtropics to high latitudes during boreal summer, J. Geophys. Res.-Atmos., 118, 8111-8127, doi:10.1002/jgrd.50636, 2013.

Postel, G. A. and Hitchman, M. H.: A climatology of Rossby wave breaking along the subtropical tropopause, J. Atmos. Sci., 56, 359-373, doi:10.1175/15200469(1999)056<0359:ACORWB>2.0.CO;2, 1999.

Preusse, P., Schroeder, S., Hoffmann, L., Ern, M., Friedl-Vallon, F., Ungermann, J., Oelhaf, H., Fischer, H., and Riese, M.: New perspectives on gravity wave remote sensing by spaceborne infrared limb imaging, Atmos. Meas. Tech., 2, 299-311, doi:10.5194/amt-2-299-2009, 2009a.

Preusse, P., Eckermann, S. D., Ern, M., Oberheide, J., Picard, R. H., Roble, R. G., Riese, M., Russell III, J. M., and Mlynczak, M. G: Global ray tracing simulations of the SABER gravity wave climatology, J. Geophys. Res.-Atmos., 114, D08126, doi:10.1029/2008JD011214, 2009b.

Preusse, P., Hoffmann, L., Lehmann, C., Alexander, M. J., Broutman, D., Chun, H.-Y., Dudhia, A., Hertzog, A., Hoepfner, M., Kim, Y.-H., Lahoz, W., Ma, J., Pulido, M., Riese, M., Sembhi, H., Wüst, S., Alishahi, V., Bittner, M., Ern, M., Fogli, P. G., Kim, S.-Y., Kopp, V., Lucini, M., Manzini, E., McConnell, J. C., Ruiz, J., Scheffler, G., Semeniuk, K., Sofieva, V., and Vial, F.: Observation of Gravity Waves from Space, Final report, ESA study, CN/22561/09/NL/AF, 195 pp., ESA-ESTEC, Netherlands, 2012.

Randel, W. J., Gille, J. C., Roche, A. E., Kumer, J. B., Mergenthaler, J. L., Waters, J. W., Fishbein, E. F., and Lahoz, W. A.:
Stratospheric transport from the tropics to middle latitudes by planetary-wave mixing, Nature, 365, 533-535, 1993.

Randel, W. J., Wu, F., and Forster, P.: The extratropical tropopause inversion layer: global observations with GPS data, and a radiative forcing mechanism, J. Atmos. Sci., 64, 4489-4496, doi:10.1175/2007JAS2412.1, 2007.

Randel, W. J., Park, M., Emmons, L., Kinnison, D., Bernath, P., Walker, K. A., Boone, C., and Pumphrey, H.: Asian monsoon transport of pollution to the stratosphere, Science, 328, 611-613, doi:10.1126/science.1182274, 2010.

Riese, M., Preusse, P., Spang, R., Ern, M., Jarisch, M., Grossmann, U., and Offermann, D.: Measurements of trace gases by the cryogenic infrared spectrometers and telescopes for the atmosphere CRISTA experiment, Adv. Space Res., 19, 563-566, doi:10.1016/S0273-1177(97)00172-5, 1997.

Riese, M., Spang, R., Preusse, P., Ern, M., Jarisch, M., Offermann, D., and Grossmann, K. U.: Cryogenic Infrared Spectrometers and Telescopes for the Atmosphere (CRISTA) data processing and atmospheric temperature and trace gas retrieval, J. Geophys. Res.-Atmos., 104, 16349-16367, doi:10.1016/S02731177(97)00172-5, 1999a.

Riese, M., Tie, X., Brasseur, G., and Offermann, D.: Threedimensional simulation of stratospheric trace gas distributions measured by CRISTA, J. Geophys. Res.-Atmos., 104, 1641916435, doi:10.1029/1999JD900178, 1999b.

Riese, M., Manney, G. L., Oberheide, J., Tie, X., Spang, R., and Küll, V.: Stratospheric transport by planetary wave mixing as observed during CRISTA-2, J. Geophys. Res.-Atmos., 107, 8179, doi:10.1029/2001JD000629, 2002.

Riese, M., Friedl-Vallon, F., Spang, R., Preusse, P., Schiller, C., Hoffmann, L., Konopka, P., Oelhaf, H., von Clarmann, T., and Höpfner, M.: GLObal limb Radiance Imager for the Atmosphere (GLORIA): scientific objectives, Adv. Space Res., 36, 989-995, doi:10.1016/j.asr.2005.04.115, 2005.

Riese, M., Ploeger, F., Rap, A., Vogel, B., Konopka, P., Dameris, M., and Forster, P.: Impact of uncertainties in atmospheric mixing on simulated UTLS composition and related radiative effects, J. Geophys. Res.-Atmos., 117, D16305, doi:10.1029/2012JD017751, 2012.

Roche, A. E., Kumer, J. B., Mergenthaler, J. L., Ely, G. A., Uplinger, W. G., Potter, J. F., James, T. C., and Sterritt, L. W.: The Cryogenic Limb Array Etalon Spectrometer (CLAES) on UARS: experiment description and performance, J. Geophys. Res.-Atmos., 98, 10763-10775, 1993.

Russell, J. M., Mlynczak, M. G., Gordley, L. L., Tansock, J., and Esplin, R.: An overview of the SABER experiment and preliminary calibration results, in: Proc. SPIE, Vol. 3756, 277-288, 1999.

Sigmond, M. and Scinocca, J. F.: The influence of the basic state on the Northern Hemisphere circulation response to climate change, J. Climate, 23, 1434-1446, doi:10.1175/2009JCLI3167.1, 2010.

Sinnhuber, B. M., Stiller, G., Ruhnke, R., von Clarmann, T., Kellmann, S., and Aschmann, J.: Arctic winter 2010/2011 at the brink of an ozone hole, Geophys. Res. Lett., 38, L24812, doi:10.1029/2011GL049784, 2011.

Solomon, S., Qin, D., Manning, M., Alley, R., Berntsen, T., Bindoff, N., Chen, Z., Chidthaisong, A., Gregory, J., Hegerl, G., Heimann, M., Hewitson, B., Hoskins, B., Joos, F., Jouzel, J., Kattsov, V., Lohmann, U., Matsuno, T., Molina, M., Nicholls, N., J.Overpeck, Raga, G., Ramaswamy, V., Ren, J., 
Rusticucci, M., Somerville, R., Stocker, T., Whetton, P., Wood, R. A., and Wratt, D.: Climate Change 2007 - the Physical Science Basis, Contribution of Working Group I to the Fourth Assessment Report of the Intergovernmental Panel on Climate Change, chap. Technical Summary, Cambridge University Press, Cambridge, UK and New York, NY, USA, 2007.

Solomon, S., Rosenlof, K. H., Portmann, R. W., Daniel, J. S., Davis, S. M., Sanford, T. J., and Plattner, G.-K.: Contributions of stratospheric water vapor to decadal changes in the rate of global warming, Science, 327, 1219-1223, doi:10.1126/science.1182488, 2010.

Son, S.-W. and Polvani, L. M.: Dynamical formation of an extra-tropical tropopause inversion layer in a relatively simple general circulation model, Geophys. Res. Lett., 34, L17806, doi:10.1029/2007GL030564, 2007.

Spang, R., Eidmann, G., Riese, M., Offermann, D., Preusse, P., Pfister, L., and Wang, P.-H.: CRISTA observations of cirrus clouds around the tropopause, J. Geophys. Res.-Atmos., 107, 8174, doi:10.1029/2001JD000698, 2002.

Spang, R., Hoffmann, L., Kullmann, A., Olschewski, F., Preusse, P., Knieling, P., Schroeder, S., Stroh, F., Weigel, K., and Riese, M.: High resolution limb observations of clouds by the CRISTA-NF experiment during the SCOUT-O3 tropical aircraft campaign, Adv. Space Res., 42, 1765-1775, doi:10.1016/j.asr.2007.09.036, 2008.

Spang, R., Arndt, K., Dudhia, A., Höpfner, M., Hoffmann, L., Hurley, J., Grainger, R. G., Griessbach, S., Poulsen, C., Remedios, J. J., Riese, M., Sembhi, H., Siddans, R., Waterfall, A., and Zehner, C.: Fast cloud parameter retrievals of MIPAS/Envisat, Atmos. Chem. Phys., 12, 7135-7164, doi:10.5194/acp-12-71352012, 2012.

Spang, R., Günther, G., Riese, M., Hoffmann, L., Müller, R., and Griessbach, S.: Satellite observations of cirrus clouds in the Northern Hemisphere lowermost stratosphere, Atmos. Chem. Phys. Discuss., 14, 12323-12375, doi:10.5194/acpd-14-123232014, 2014.

Spichtinger, P., Gierens, K., and Wernli, H.: A case study on the formation and evolution of ice supersaturation in the vicinity of a warm conveyor belt's outflow region, Atmos. Chem. Phys., 5, 973-987, doi:10.5194/acp-5-973-2005, 2005.

Taylor, F., Rodgers, C., Whitney, J., Werrett, S., Barnett, J., Peskett, G., Venters, P., Ballard, J., Palmer, C., Knight, R., Morris, P., Nightingale, T., and Dudhia, A.: Remote-sensing of atmospheric structure and composition by pressure modulator radiometry from space - the ISAMS experiment on UARS, J. Geophys. Res.-Atmos., 98, 10799-10814, doi:10.1029/92JD03029, 1993.

Ungermann, J., Kaufmann, M., Hoffmann, L., Preusse, P., Oelhaf, H., Friedl-Vallon, F., and Riese, M.: Towards a 3-D tomographic retrieval for the air-borne limb-imager GLORIA, Atmos. Meas. Tech., 3, 1647-1665, doi:10.5194/amt-3-1647-2010, 2010.

Ungermann, J., Blank, J., Lotz, J., Leppkes, K., Hoffmann, L., Guggenmoser, T., Kaufmann, M., Preusse, P., Naumann, U., and Riese, M.: A 3-D tomographic retrieval approach with advection compensation for the air-borne limb-imager GLORIA, Atmos. Meas. Tech., 4, 2509-2529, doi:10.5194/amt-4-2509-2011, 2011.

Ungermann, J., Kalicinsky, C., Olschewski, F., Knieling, P., Hoffmann, L., Blank, J., Woiwode, W., Oelhaf, H., Hösen, E.,
Volk, C. M., Ulanovsky, A., Ravegnani, F., Weigel, K., Stroh, F., and Riese, M.: CRISTA-NF measurements with unprecedented vertical resolution during the RECONCILE aircraft campaign, Atmos. Meas. Tech., 5, 1173-1191, doi:10.5194/amt-5-11732012, 2012.

Ungermann, J., Pan, L. L., Kalicinsky, C., Olschewski, F., Knieling, P., Blank, J., Weigel, K., Guggenmoser, T., Stroh, F., Hoffmann, L., and Riese, M.: Filamentary structure in chemical tracer distributions near the subtropical jet following a wave breaking event, Atmos. Chem. Phys., 13, 10517-10534, doi:10.5194/acp13-10517-2013, 2013.

Vogel, B., Pan, L. L., Konopka, P., Günther, G., Müller, R., Hall, W., Campos, T., Pollack, I., Weinheimer, A., Wei, J., Atlas, E. L., and Bowman, K. P.: Transport pathways and signatures of mixing in the extratropical tropopause region derived from Lagrangian model simulations, J. Geophys. Res.-Atmos., 116, D05306, doi:10.1029/2010JD014876, 2011.

Vogel, B., Günther, G., Müller, R., Grooß, J.-U., Hoor, P., Krämer, M., Müller, S., Zahn, A., and Riese, M.: Fast transport from Southeast Asia boundary layer sources to Northern Europe: Rapid uplift in typhoons and eastward eddy shedding of the Asian monsoon anticyclone, Atmos. Chem. Phys. Discuss., submitted, 2014.

von Hobe, M., Bekki, S., Borrmann, S., Cairo, F., D’Amato, F., Di Donfrancesco, G., Dörnbrack, A., Ebersoldt, A., Ebert, M., Emde, C., Engel, I., Ern, M., Frey, W., Genco, S., Griessbach, S., Grooß, J.-U., Gulde, T., Günther, G., Hösen, E., Hoffmann, L., Homonnai, V., Hoyle, C. R., Isaksen, I. S. A., Jackson, D. R., Jánosi, I. M., Jones, R. L., Kandler, K., Kalicinsky, C., Keil, A., Khaykin, S. M., Khosrawi, F., Kivi, R., Kuttippurath, J., Laube, J. C., Lefèvre, F., Lehmann, R., Ludmann, S., Luo, B. P., Marchand, M., Meyer, J., Mitev, V., Molleker, S., Müller, R., Oelhaf, H., Olschewski, F., Orsolini, Y., Peter, T., Pfeilsticker, K., Piesch, C., Pitts, M. C., Poole, L. R., Pope, F. D., Ravegnani, F., Rex, M., Riese, M., Röckmann, T., Rognerud, B., Roiger, A., Rolf, C., Santee, M. L., Scheibe, M., Schiller, C., Schlager, H., Siciliani de Cumis, M., Sitnikov, N., Søvde, O. A., Spang, R., Spelten, N., Stordal, F., Sumińska-Ebersoldt, O., Ulanovski, A., Ungermann, J., Viciani, S., Volk, C. M., vom Scheidt, M., von der Gathen, P., Walker, K., Wegner, T., Weigel, R., Weinbruch, S., Wetzel, G., Wienhold, F. G., Wohltmann, I., Woiwode, W., Young, I. A. K., Yushkov, V., Zobrist, B., and Stroh, F.: Reconciliation of essential process parameters for an enhanced predictability of Arctic stratospheric ozone loss and its climate interactions (RECONCILE): activities and results, Atmos. Chem. Phys., 13, 92339268, doi:10.5194/acp-13-9233-2013, 2013.

Weigel, K., Riese, M., Hoffmann, L., Hoefer, S., Kalicinsky, C., Knieling, P., Olschewski, F., Preusse, P., Spang, R., Stroh, F., and Volk, C. M.: CRISTA-NF measurements during the AMMASCOUT-O3 aircraft campaign, Atmos. Meas. Tech., 3, 14371455, doi:10.5194/amt-3-1437-2010, 2010.

Weigel, K., Hoffmann, L., Günther, G., Khosrawi, F., Olschewski, F., Preusse, P., Spang, R., Stroh, F., and Riese, M.: A stratospheric intrusion at the subtropical jet over the Mediterranean Sea: air-borne remote sensing observations and model results, Atmos. Chem. Phys., 12, 8423-8438, doi:10.5194/acp12-8423-2012, 2012.

Werner, A., Volk, C. M., Ivanova, E. V., Wetter, T., Schiller, C., Schlager, H., and Konopka, P.: Quantifying transport into the 
Arctic lowermost stratosphere, Atmos. Chem. Phys., 10, 1162311639, doi:10.5194/acp-10-11623-2010, 2010.

Wetzel, G., Oelhaf, H., Kirner, O., Ruhnke, R., Friedl-Vallon, F., Kleinert, A., Maucher, G., Fischer, H., Birk, M., Wagner, G., and Engel, A.: First remote sensing measurements of $\mathrm{ClOOCl}$ along with $\mathrm{ClO}$ and $\mathrm{ClONO}_{2}$ in activated and deactivated Arctic vortex conditions using new $\mathrm{ClOOCl}$ IR absorption cross sections, Atmos. Chem. Phys., 10, 931-945, doi:10.5194/acp-10-931-2010, 2010.

Wetzel, G., Oelhaf, H., Kirner, O., Friedl-Vallon, F., Ruhnke, R., Ebersoldt, A., Kleinert, A., Maucher, G., Nordmeyer, H., and Orphal, J.: Diurnal variations of reactive chlorine and nitrogen oxides observed by MIPAS-B inside the January 2010 Arctic vortex, Atmos. Chem. Phys., 12, 6581-6592, doi:10.5194/acp12-6581-2012, 2012.

Wiegele, A., Kleinert, A., Oelhaf, H., Ruhnke, R., Wetzel, G., Friedl-Vallon, F., Lengel, A., Maucher, G., Nordmeyer, H., and Fischer, H.: Spatio-temporal variations of $\mathrm{NO}_{\mathrm{y}}$ species in the northern latitudes stratosphere measured with the balloonborne MIPAS instrument, Atmos. Chem. Phys., 9, 1151-1163, doi:10.5194/acp-9-1151-2009, 2009.
Wirth, V.: Static stability in the extratropical tropopause region, J. Atmos. Sci., 60, 1395-1409, doi:10.1175/15200469(2003)060<1395:SSITET>2.0.CO;2, 2003.

WMO: Scientific Assessment of Ozone Depletion: 2010, Global Ozone Research and Monitoring Project, 52, Geneva, Switzerland, 2011.

Woiwode, W., Oelhaf, H., Gulde, T., Piesch, C., Maucher, G., Ebersoldt, A., Keim, C., Höpfner, M., Khaykin, S., Ravegnani, F., Ulanovsky, A. E., Volk, C. M., Hösen, E., Dörnbrack, A., Ungermann, J., Kalicinsky, C., and Orphal, J.: MIPAS-STR measurements in the Arctic UTLS in winter/spring 2010: instrument characterization, retrieval and validation, Atmos. Meas. Tech., 5, 1205-1228, doi:10.5194/amt-5-1205-2012, 2012.

Xiao, Y. P., Logan, J. A., Jacob, D. J. Hudman, R. C., Yantosca, R., and Blake, D. R.: Global budget of ethane and regional constraints on US sources, J. Geophys. Res.-Atmos., 113, D21306, doi:10.1029/2007JD009415, 2008. 